\title{
On the action of some diuretica and other drugs upon the glomeruli.
}

\author{
By \\ Masanori Okada. \\ From the physiological Department of University, Okayama. \\ (Director: Prof. Dr. S. Oinuma) \\ Received for publicntion, September 19, 1927,
}

Substances which, when they enter the blood stream, increase the amount of urine formed by the kidneys are called diuretics and their diuretic action is produced by the increase of filtration in the glomeruli, or provention of absorption in the tubles, or cooperation of these two processes. The increase of filtration in the glomeruli is caused by the following three cases.

1. Rise of blood pressure in the renal arterial system.

2. Velocity of blood flow in the kidney.

3. Hydraemia.

Diuretics are to have some one of these actions.

Since a long time, the experiments about the action of drugs upon the kidney have been performed by means of perfusion experiment or with oncometer. But in these experimental methods it can not be decided whether the action of drugs is upon the renal arteries or upon glomerular capillaries.

Hill and McQueen described experiments on glomerular capillary pressure in which they took direct observation of the frog's kidney.

Richards and Schmidt observed the state of glomerular circulation in the frog's kidney and the action of various drugs upon it.

Method of illumination and observation used by the latter two, was such as had been used by Krogh in his study of capillaries in muscles.

They reported that; when the experiment was conducted with minimal or no blood loss, a considerable increase in the number of glomeruli which received blood could be brought about by injection of urea, caffeine, glucose, and sodium sulphate, but on the other hand, decrease in the number of glomeruli which received blood could be effected by large doses of pituitrin and adrenalin.

I made the following experiments to examine the increase and decrease of the number of glomeruli and variation of the state of circulation in the glomerular capillaries through which blood flows, applying directly each solution of some diuretics and of other drugs to the exposed kidney of frog under observation with the microscope. 


\section{Method.}

As I have mentioned in my previous papers, Rena nigromneulnta was used in the mnjority of experiments. The animal was narcotized wenkly with curam and then brain was destroyed. The lridney was exposed by longitudinal abdominnl incision.

Illuminntion of the kidney wns best secured by menns of an arc-lamp. The rnys were condenced and then were cooled by passing throngh a lnyer of water tinged with methylen blue.

A drop of solution of some diuretios and of other drugs were plnced by menns of a fine glass capillary whioh has been made as fine as possible, on the glomeruli in the hidney under observation with the microsoope or a solution of these drugs was injected into the anterjor abdominnl vein in amounts of $0.05-$ 0,1 co and the following results were obtuined.

\section{Caffeine.}

It has been known for a long time that caffeine causes dilatation of the blood vessels, and as I have mentioned in my previous papers, the blood capillaries are also dilated by it.

Doughss Cow found that caffeine, whilst moderately dilating the renal artery, produced an equal nmount of dihtation in the case of the splenic artery but had no apprecinble effect on the curotid artery.

When a drop of a solution stronger than 0.2 p. c. was placed on the glomeruli, the glomerular capillaries were dilated and accordingly the quantity of blood which flows

The following table shows the results of these experiments.

\begin{tabular}{|c|c|c|c|c|c|}
\hline \multirow{2}{*}{ Case. } & \multirow{2}{*}{$\begin{array}{c}\text { Concentrution. } \\
\%\end{array}$} & \multirow{2}{*}{$\begin{array}{l}\text { Variation of dinmeter } \\
\text { of glomerulur } \\
\text { cipillaries. }\end{array}$} & \multicolumn{2}{|c|}{$\begin{array}{c}\text { Variation of the } \\
\text { number of glomeruld. }\end{array}$} & \multirow{2}{*}{$\begin{array}{l}\text { Variution of circulation } \\
\text { in the glomeruli. }\end{array}$} \\
\hline & & & $\left|\begin{array}{c}\text { Before } \\
\text { npplicntion }\end{array}\right|$ & $\begin{array}{c}\text { After } \\
\text { appliant }\end{array}$ & \\
\hline 1 & 0.2 & & 3 & 5 & \\
\hline 2 & $\prime \prime$ & & 3 & 4 & \\
\hline 3 & " & dilistuted slightly. & 5 & 7 & becume more rupid. \\
\hline 4 & $" 1$ & & 4 & 4 & \\
\hline 5 & $" 1$ & & 5 & 7 & \\
\hline 1 & 0.5 & & 4 & 7 & \\
\hline 2 & $" \prime$ & & 6 & 8 & \\
\hline 3 & " & dilnted. & 5 & 8 & becrme more rapid. \\
\hline 4 & " & . & 6 & 7 & \\
\hline 5 & $" \prime$ & & 8 & 10 & \\
\hline $\mathbf{1}$ & 1.0 & & 3 & 6 & \\
\hline 2 & $" \prime$ & . & 4 & 7 & \\
\hline 3 & $" \prime$ & diluted extremely. & 7 & 10 & $\begin{array}{l}\text { becrme much } \\
\text { more mpid. }\end{array}$ \\
\hline 4 & $" \prime$ & & 5 & 9 & \\
\hline 5 & $\prime \prime$ & & 7 & 11 & \\
\hline
\end{tabular}


through the glomerular capillaries was increased and the circulation in the glomerular capillaries became much more rapid. The glomeruli which had hitherto been stationary, became active and were congested and swollen.

A number of glomeruli unobserved until then became visible.

When a solution of caffeine stronger than $0.1 \mathrm{p}$. c. was injected into the anterior abdominal vein in amounts of $0.05-0.1 \mathrm{cc}$, the same resultes were obtained.

\section{Caffeine sodio-benzoate.}

When Caffeine sodio-benzoate was dropped on the glomeruli or injected into the anterior abdominal vein in amounts of $0.05-0.1 \mathrm{ce}$ the same results were obtained as caffeine.

But the dilator effect produced by caffeine was generally more marked than that produced by caffeine sodio-benzoate.

\section{Theocin and glucose (isotonic with $0.6 \%$ Ringer's solution).}

These drugs had no effect upon the glomeruli when each drop of these drugs was placed on the exposed kidney surface or injected into the anterior abdominal vein.

\section{Diuretin.}

A solution stronger than 0.1 p. c. caused dilatation of glomerular capillaries, when it was dropped on the glomeruli or injected into the anterior abdominal vein and the circulation in the glomerular capillarie became more rapid. The quantity of blood which flows through the glomerular capillaries increased and accordingly the glomeruli got congested and swollen. The number of glomeruli increased.

The results of this experiment are shown in the following table.

\begin{tabular}{|c|c|c|c|c|c|}
\hline \multirow{2}{*}{ Cuse. } & \multirow{2}{*}{$\begin{array}{c}\text { Concentration. } \\
\%\end{array}$} & \multirow{2}{*}{$\begin{array}{l}\text { Variution of dinmeter } \\
\text { of glomerular } \\
\text { cipilliries. }\end{array}$} & \multicolumn{2}{|c|}{$\begin{array}{l}\text { Varintion of the } \\
\text { number of glomeruli. }\end{array}$} & \multirow{2}{*}{$\begin{array}{l}\text { Varintion of the state } \\
\text { of circulntion in } \\
\text { the glomeruli. }\end{array}$} \\
\hline & & & $\begin{array}{c}\text { Before } \\
\text { upplication }\end{array}$ & $\begin{array}{c}\text { After } \\
\text { applicat. }\end{array}$ & \\
\hline 1 & 0.1 & & 7 & 8 & \\
\hline 2 & $"$ & & $\cdot 3$ & 5 & \\
\hline 3 & $" 1$ & Dilated slightly. & 6 & 6 & became more rapid, \\
\hline 4 & " & & 4 & 5 & \\
\hline 5 & $" \prime$ & & 4 & 6 & \\
\hline
\end{tabular}




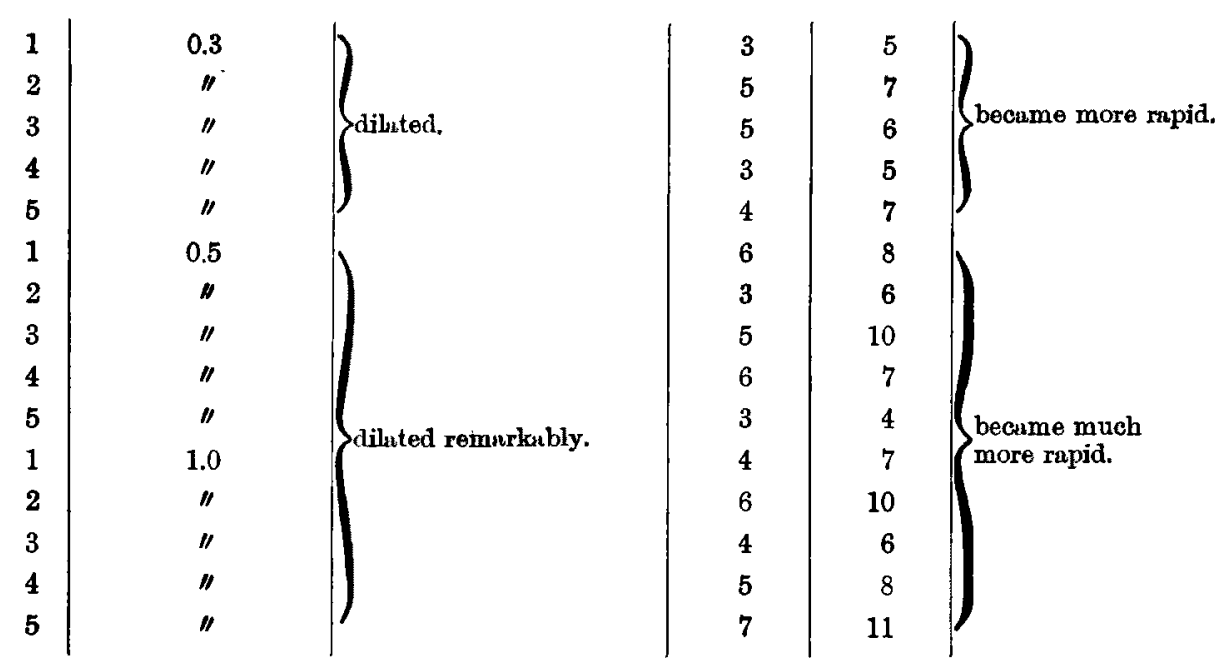

\section{Liquor kalii acetici (Solution of potassium acetate).}

When a solution stronger than 0.1 p. c. was applied in drops to the exposed hidney, the glomerular capillaries contracted and also the efferent- and afferent vessels contracted. The blood flow in the glomerular capillaries became remarkably slow and the quantity of blood which flows through them decreased. The glomeruli, hitherto active, became stationary and a number of glomeruli diminished.

The following table shows the results of this experiment.

\begin{tabular}{|c|c|c|c|c|c|}
\hline \multirow{2}{*}{ Cuse. } & \multirow{2}{*}{$\begin{array}{c}\text { Concentration. } \\
\%\end{array}$} & \multirow{2}{*}{$\begin{array}{l}\text { Variation of diameter } \\
\text { of glomerular } \\
\text { cupilluries. }\end{array}$} & \multicolumn{2}{|c|}{$\begin{array}{c}\text { Varintion of the } \\
\text { number of glomeruli. }\end{array}$} & \multirow{2}{*}{$\begin{array}{l}\text { Vuriation of circulation } \\
\text { in the glomeruli. }\end{array}$} \\
\hline & & & $\begin{array}{c}\text { Before } \\
\text { npplication }\end{array}$ & $\begin{array}{c}\text { After } \\
\text { npplient }\end{array}$ & \\
\hline 1 & 0.1 & & 5 & 3 & \\
\hline 2 & $"$ & & 4 & 1 & \\
\hline 3 & $\prime \prime$ & contracted. & 3 & 1 & $\begin{array}{l}\text { became slow } \\
\text { remarkably. }\end{array}$ \\
\hline 4 & $"$ & & 4 & 0 & \\
\hline 5 & $" \prime$ & & 5 & 1 & \\
\hline 1 & 0.3 & & 3 & 0 & \\
\hline 2 & $" 1$ & & 5 & 1 & \\
\hline 3 & "l & contracted & 6 & 0 & stopped in all ctuses. \\
\hline 1 & 0.5 & remurkably. & 5 & 0 & \\
\hline 2 & $" \prime$ & & 3 & 0 & \\
\hline 3 & $" \prime$ & & 7 & 1 & \\
\hline
\end{tabular}




\section{Kreatin.}

A solution stronger than 0.2 p. c. caused dilatation of glomerular capillaries and the circulation in them became more rapid.

The quantity of blood flowing through them increased and accordingly the glomeruli got congested and swollen.

A number of glomeruli, hitherto unobserved, became visible.

\section{Guanidin.}

When a drop of solution weaker than 0.4 p. c. was applied to the exposed kidney, the glomerular capillaries were dilated and the circulation in them became more rapid. The glomeruli were congested and swollen, their number increasing in number. But on the contrary, a solution stronger than 0.5 p. c., when it was dropped on the kidney, caused contraction of glomerular capillaries and the quantity of blood which flows through them decreased.

The glomeruli, hitherto observed, became invisible.

When a 0.5 p. c. solution was injected in amount of $0.05 \mathrm{cc}$ into the anterior abdominal vein, the circulation in the glomerular capillaries at first became more rapid and the quantity of blood flowing throngh them increased. But in no time the glomerular capillaries began to contract and the circulation in them stopped.

The following table shows the action of guanidin in varions concentrations.

\begin{tabular}{|c|c|c|c|c|c|}
\hline \multirow{2}{*}{ Casse. } & \multirow{2}{*}{$\begin{array}{c}\text { Concentrution. } \\
\%\end{array}$} & \multirow{2}{*}{$\begin{array}{l}\text { Variation of dinmeter } \\
\text { of glomerulur } \\
\text { capillaries. }\end{array}$} & \multicolumn{2}{|c|}{$\begin{array}{c}\text { Varintion of the } \\
\text { number of glomeruli. }\end{array}$} & \multirow{2}{*}{$\begin{array}{l}\text { Va.tintion of the state } \\
\text { of circulation in the } \\
\text { glomeruli. }\end{array}$} \\
\hline & & & $\begin{array}{c}\text { Before } \\
\text { appliantion. }\end{array}$ & $\begin{array}{c}\text { After } \\
\text { applicat. }\end{array}$ & \\
\hline 1 & 0.3 & & 5 & 6 & \\
\hline$\cdot 2$ & "I & & 4 & 7 & \\
\hline 3 & $" \prime$ & diluted. & 3 & 3 & becume more rapid. \\
\hline 4 & $" 1$ & & 4 & 6 & \\
\hline $\mathbf{5}$ & $\prime \prime$ & & 3 & 4 & \\
\hline 1 & 0.5 & & 6 & 4 & \\
\hline 2 & " & & 3 & 1 & \\
\hline 3 & " & ontructed. & 5 & 4 & $\begin{array}{l}\text { becume remarkably } \\
\text { slow or stopped. }\end{array}$ \\
\hline 4 & $\|$ & & $\mathbf{3}$ & 2 & \\
\hline 5 & $\prime \prime$ & & 7 & 5 & \\
\hline 1 & 0.8 & & 3 & 0 & \\
\hline 2 & $\|$ & & 7 & 3 & \\
\hline 3 & $" l$ & $\begin{array}{l}\text { eontrueted } \\
\text { remarkubly! }\end{array}$ & 4 & 1 & stopped in all cuses. \\
\hline 4 & 11 & & 6 & 2 & \\
\hline 5 & $" 1$ & & 5 & 1 & \\
\hline
\end{tabular}


The glomeruli, hitherto active, became stationary and at the same time a number of them became invisible.

During these experiments, when the convulsion occured, the glomerular capillaries contracted without exception.

\section{Sodium salts and potassium salts.}

Various sodium salts and potassium salts which are isotonic with 0.6 p. c. Ringer's solution, were used.

It has been known for many years that the nitrites produce vaso dilatation.

Brunton, as long ago as in 1870, concluded that the lowering of blood pressure cuused by nitrites, is due not to werkening of the hearts uction, but to a dilatution of the vessels, und that this dilutation is due to the direct action of the drug upon the walls of vessels.

$\mathrm{NaNO}_{3}, \mathrm{NaNO}_{2}$ and $\mathrm{Na}_{2} \mathrm{HPO}_{4}$ caused slight dilatation of the glomerular capillaries and the circulation in them became more rapid.

The quantity of blood flowing through them slightly increased.

Other sodium salts had no effect upon the glomeruli.

On the other hand, all the potassium salts caused a remarkable constriction of glomerular capillaries without exception. And the quantity of blood which flows through them decreased remarkably.

All of the glomeruli, hitherto active, became stationary and at last became invisible.

The following table shows the results of this experiment.

\begin{tabular}{|c|c|c|c|c|c|}
\hline \multirow{2}{*}{ Drugs. } & \multirow{2}{*}{$\begin{array}{l}\text { Concentra } \\
\text { tion. } \\
\%\end{array}$} & \multirow{2}{*}{$\begin{array}{l}\text { Variation of dinmeter } \\
\text { of glomerulur } \\
\text { capillaries. }\end{array}$} & \multicolumn{2}{|c|}{$\begin{array}{c}\text { Varintion of the } \\
\text { number of glomeruli. }\end{array}$} & \multirow{2}{*}{$\begin{array}{l}\text { Varintion of the stute } \\
\text { of eirculation in the } \\
\text { glomeruli. }\end{array}$} \\
\hline & & & $\begin{array}{c}\text { Before } \\
\text { applicaticn. }\end{array}$ & $\begin{array}{c}\text { After } \\
\text { npplicut. }\end{array}$ & \\
\hline $\mathrm{NaBr}$ & 1.3 & no change. & 5 & 5 & no change. \\
\hline $\mathrm{NaNO}_{8}$ & 1.0 & & 4 & 5 & \\
\hline $\mathrm{NaNO}_{2}$ & 0.8 & diluted slightly. & 3 & 5 & became more mpid. \\
\hline $\mathrm{Na}_{2} \mathrm{HPO}_{4}$ & 2.4 & & 6 & 7 & \\
\hline $\mathrm{NaJ}$ & 1.8 & & 4 & 4 & \\
\hline $\mathrm{Na}_{2} \mathrm{SO}_{4}$ & 1.5 & no chinge. & 3 & 3 & no chunge. \\
\hline $\mathrm{NaHCO}_{3}$ & 0.9 & & 8 & 8 & \\
\hline $\mathbf{K B r}$ & 1.5 & & 7 & 1 & \\
\hline $\mathrm{KNO}_{3}$ & 1.2 & & 3 & $\dot{0}$ & \\
\hline KCl & 0.9 & & 4 & 0 & \\
\hline $\mathbf{K J}$ & 1.4 & contructed & 8 & 1 & \\
\hline $\mathrm{K}_{2} \mathrm{CO}_{3}$ & 1.2 & remurkubly, & 5 & 0 & completely. \\
\hline $\mathrm{KClO}_{3}$ & 1.2 & & 6 & 1 & \\
\hline $\mathbf{K S}_{2} \mathrm{O}_{4}$ & 1.5 & & 3 & 0 & \\
\hline $\mathrm{KClO}$ & 0.9 & & 7 & 0 & \\
\hline
\end{tabular}


A drop of 0.1 p. c. solution of these potassium salts was applied to the kidney surface or injected into the anterior abdominal vein in amounts of $0.05-0.1 \mathrm{cc}$ and the same results were obtained.

\section{Calcium salts and Magnesium salts.}

Hans Meyer has shown that the administration of calcium sults jnhibits inflamatory exsudation, and that withdrawal of the normal anlcium salts produce a byperirritnbility of the sympathetio system towards adrenalin and other drugs. Douglas Cow found that when the arterinl ring was placed in calcium free saline solution, and adrennlin and pituitrin instilled, a grenter renction occurred than followed by equal doses of these drugs when the experiment was performed in saline solution contrining an excess of caloium salts.

$1.0 \% \mathrm{CaCl}_{2}, 1.5 \% \mathrm{Ca}_{2} \mathrm{NO}_{3}, 2.1 \% \mathrm{CaH}_{4}\left(\mathrm{PO}_{4}\right)_{2}, 1.5 \% \mathrm{MgCl}_{2}$ and $4.5 \% \mathrm{MgSO}_{4}$ were used and they are isotonic with $0.6 \%$ Ringer's solution.

All of these calcium salts and magnesium salts caused dilatation of glomerular capillaries and the circulation in them became much more rapid.

The glomeruli were congested and swollen and the number of them increased.

A 0.5 p.c. solution of these salts was dropped on the kidney or injected into the anterior abdominal vein and the same results were obtained.

In these experiments it seems that the effect of calcium salts is weaker than that of magnesium salts.

These results are shown in the following table.

\begin{tabular}{|c|c|c|c|c|c|}
\hline \multirow{2}{*}{ Drugs. } & \multirow{2}{*}{$\begin{array}{c}\text { Concentrin- } \\
\text { tion. } \\
\%\end{array}$} & \multirow{2}{*}{$\begin{array}{l}\text { Varintion of dinmeter } \\
\text { of glomerulhr } \\
\text { cupillnries. }\end{array}$} & \multicolumn{2}{|c|}{$\begin{array}{l}\text { Vurintion of the } \\
\text { number of glomeruli. }\end{array}$} & \multirow{2}{*}{$\begin{array}{c}\text { Variation of the state } \\
\text { of eireulntion in the } \\
\text { glomeruli. }\end{array}$} \\
\hline & & & $\begin{array}{c}\text { Before } \\
\text { nppliention. }\end{array}$ & $\begin{array}{c}\text { After } \\
\text { applicnt. }\end{array}$ & \\
\hline $\mathrm{CaCl}_{2}$ & 1.0 & & 4 & 6 & \\
\hline$n$ & $z$ & & 3 & 5 & \\
\hline $\mathrm{Ca}_{4} \mathrm{NO}_{3}$ & 1.5 & & 3 & 4 & \\
\hline$"$ & $" 1$ & & 5 & 7 & \\
\hline $\mathrm{CaH}_{4}\left(\mathrm{PO}_{4}\right)_{2}$ & 2.1 & molrol & 4 & 6 & onme much \\
\hline " & $" 1$ & ea reminkad & 6 & 8 & ore mpid. \\
\hline $\mathbf{M g C l}_{2}$ & 1.5 & & 3 & 6 & \\
\hline$" 1$ & $\|$ & & 5 & 8 & \\
\hline $\mathrm{MgSO}_{4}$ & 4.5 & & 4 & 9 & \\
\hline$"$ & $\|$ & & 3 & 7 & \\
\hline
\end{tabular}




\section{Some organic substances.}

A solution stronger than $\frac{\mathrm{m}}{100}$ in density of these substances always produced a remarkable dilatation of glomerular capillaries and accordingly the circulation in them became much more rapid with the increase of the quantity of blood which flows through them.

The glomeruli, hitherto stationary, became active and the number of them iecreased. When a drop of 0.1 p.c. solution of potassium salts was dropped on the kidney surface, the glomeruli observed till then, became invisible and as soon as a drop of $\frac{m}{100}$ solution of hydrochinon was applied to that kiduey, the glomeruli remaining unobserved became visible and active.

The following table shows the results of this experiment.

\begin{tabular}{|c|c|c|c|c|c|}
\hline \multirow{2}{*}{ Drtugs. } & \multirow{2}{*}{$\begin{array}{c}\text { Concentra- } \\
\text { tion. }\end{array}$} & \multirow{2}{*}{$\begin{array}{l}\text { Varintion of diumeter } \\
\text { of glomerulur } \\
\text { ctpilluries. }\end{array}$} & \multicolumn{2}{|c|}{$\begin{array}{l}\text { Variation of the } \\
\text { number of glomernli. }\end{array}$} & \multirow{2}{*}{$\begin{array}{l}\text { Variation of the state } \\
\text { of circulution in the } \\
\text { glomeruli. }\end{array}$} \\
\hline & & & $\begin{array}{r}\text { Before } \\
\text { npplicat. }\end{array}$ & $\begin{array}{c}\text { After } \\
\text { applicat. }\end{array}$ & \\
\hline Bydrochinon. & $\frac{m}{100}$ & & 4 & 6 & \\
\hline$" 1$ & $" 1$ & & 4 & 7 & \\
\hline$"$ & $\frac{\mathrm{m}}{10}$ & . & 3 & 5 & \\
\hline$" \prime$ & $"$ & & 5 & 11 & \\
\hline Phrologultin. & $\frac{\mathrm{m}}{100}$ & & 3 & 4 & \\
\hline$" \prime$ & $"$ & dilnted & 6 & 7 & became much \\
\hline$"$ & $\mathrm{~m}$ & remarkably. & 5 & 7 & ore nonid \\
\hline$\|$ & $" 1$ & & 3 & 5 & \\
\hline Pyrogallol. & $\frac{\text { m }}{100}$ & & 7 & 9 & \\
\hline$" n$ & 1 & & 3 & 5 & \\
\hline II & $\frac{m}{10}$ & $\cdot$ & 6 & 10 & \\
\hline$" 1$ & 11 & & 4 & 8 & \\
\hline
\end{tabular}

\section{Summary.}

From the results of my experiments the conclusion may be summarized as follows.

1. Caffeine, caffeine sodio-benzoate and diuretin have dilator effect upon the glomerular capillaries and the circulation in them becomes more rapid. The quantity of blood which flows through them increases and a number of glomeruli, hitherto unobserved, become visible.

On the other hand, theocin and glucose have no effect upon the glomeruli.

2. Solution of potassium acetate causes a remarkable contraction and at the same time the glomeruli till then observed, become invisible. 
3. Kreatin produces, a dilatation of glomerular capillaries and accordingly the circulation in them becomes more rapid and also the number of glomeruli increased.

Guanidin in a solution weaker than 0.4 p. c. causes dilatation of glomerular capillaries and increase of the quantity of blood which flows through them and also it causes the increase of verocity of blood flow in the glomerular capillaries. The glomeruli, hitherto stationary, become active and the number of them increases.

On the contrary, a solution stronger than $0.5 \mathrm{p}$. c. always causes contraction of glomerular capillaries and the number of glomeruli are decreased.

4. Isotonic solution (with $0.6 \%$ Ringer's solution) of $\mathrm{NaNO}_{2}, \mathrm{NaNO}_{3}$ and $\mathrm{Na}_{2} \mathrm{HPO}_{4}$ causes a slight dilatation of glomerular capillaries and accordingly the increase of verocity of blood flow in them and of quantity of blood flowing through them are produced.

But other sodium salts have no effect upon the glomeruli.

All of potassium salts, on the contrary, have an opposite effect upon the glomeruli to that of sodium salts.

5. Calcium salts and magnesium salts (isotonic with $0.6 \%$ Ringer's solution) and some organic substances ( $\frac{\mathrm{m}}{100}$ in density) have a remarkable dilator effect upou the glomerular capillaries and cause the increase of verocity of blood flow in them and of quantity of blood which flows through them. Glomeruli are increased in number und are remarkably congested and swollen.

In conclusion, allow me to give my henrty thanks for my indebtedness to Prof, S. Oinuma,

\section{Bibliography.}

1) Barcroft and Staub, Journ. of physiol, vol. 41, 1910.02 2) Brunton, Journ. of Anat. and physiol, vol. 5, p. 92 . 3) Dale and Richards, Journ. of physiol. vol. 52, 1918-19. Journ, of physiol, vol. 42, 1911. 5) Gaskel, Journ. of physiol, vol. 3 p. 48, 1882. 6) Hins Meyer, Brit. Med. Journ. vol. 11, p. 19, 1910, 7) Houghton and Merill, Journ. of Amer. Med, Ass. No. 28 p. 1849,1908 . 8) Hoocker, Amer. Journ. of physiol. vol. $28,1911.9$ 9) Krogh, Journ. of physiol. vol, 52, p. 457, 1919. 10) Krogh, Journ. of physiol, vol. 53, p. 399, 1920. 11) Richards and Plant, Amer. Journ, physiol, vol. 59, 1922. 12) Richards and Schmidt, Amer. Journ. physiol, vol, 71, p. 178, 1925. 13) Stiles, Amer. Journ. physiol, vol, 5, p. 338, 1901. 14) Turchanoff, Phlüger Areh. Bd. 9, S. 407,1874 . 
內 容大意

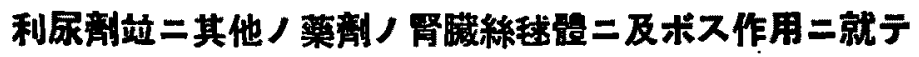

\author{
岡山蜜科大學生理學敢肎 (主任生沼票授)
}

阔 田 正 矩

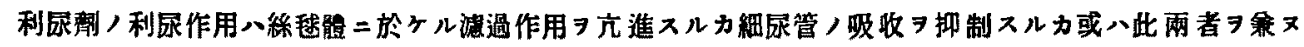

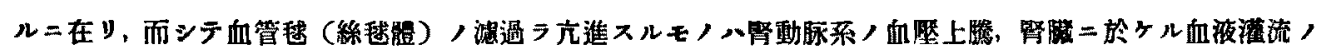

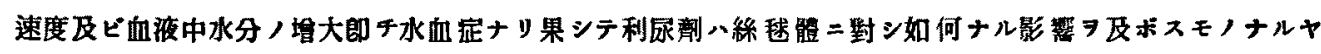

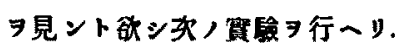

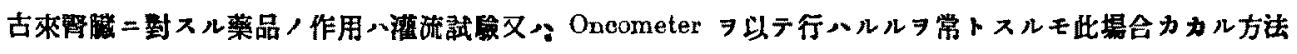

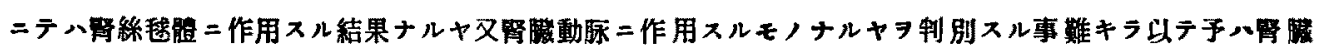

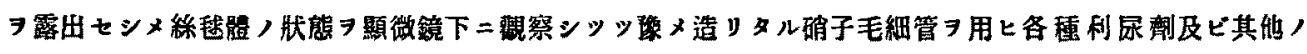

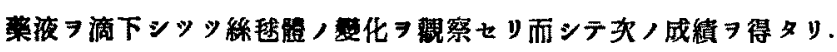

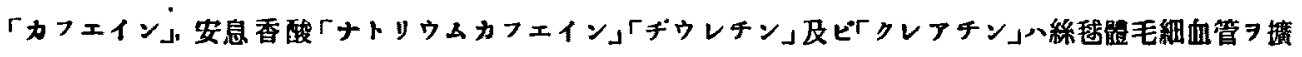

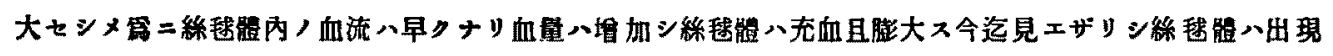

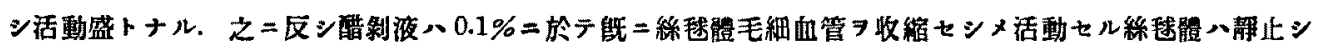
濑次其数习減ズ。

「テネチン」「葡萄糖」ハ何等, 影響

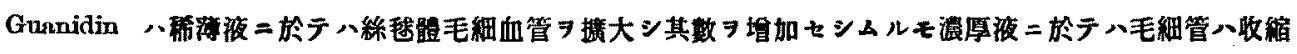

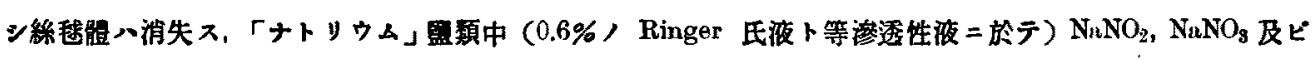

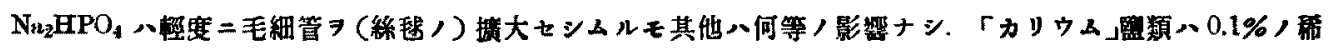

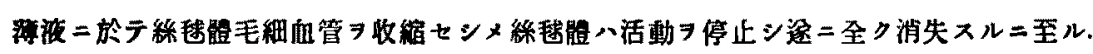

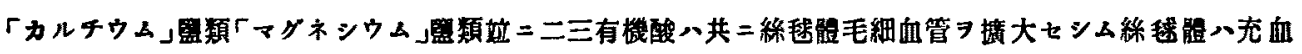

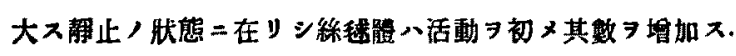

